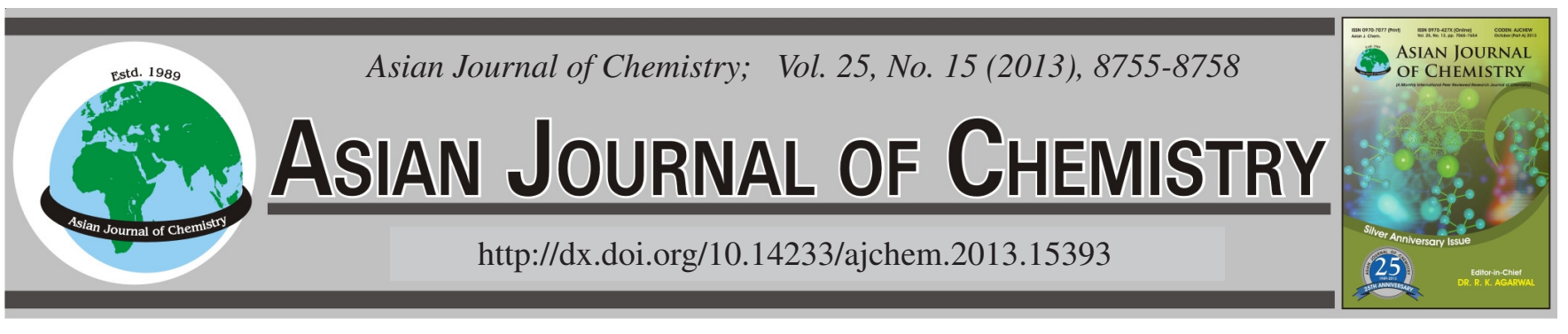

\title{
Content and Background Concentrations of Heavy Metals in the Sediment of Urban River in Northern Anhui Province, China
}

\author{
Song Chen ${ }^{1,2, *}$ and Xuehai Fu ${ }^{1}$ \\ ${ }^{1}$ School of Resource and Earth Science, China University of Mining and Technology, Xuzhou 221116, Jiangsu Province, P.R. China \\ ${ }^{2}$ School of Earth Sciences and Engineering, Suzhou University, Suzhou 234000, Anhui Province, P.R. China \\ *Corresponding author: E-mail: szxychensong@163.com
}

(Received: 27 February 2013;

Accepted: 29 August 2013)

AJC-14041

\begin{abstract}
The concentrations of 16 chemical elements in the sediment samples from urban river were measured at the northern Anhui province, China. Based on correlation coefficients and regression analysis, the relationships among these elements of 37 sediment samples were studied. The element $\mathrm{Al}$ was selected as the reference element for $\mathrm{Cr}, \mathrm{Zn}, \mathrm{V}$ and $\mathrm{Cu}$, while $\mathrm{Fe}$ was used as the reference element for $\mathrm{Co}$, $\mathrm{Mn}, \mathrm{As}$ and $\mathrm{Pb}$. The regional geochemical baseline models of these heavy metals were obtained by the linear baseline model. The background concentrations of these heavy metals were calculated using the selected sediment samples which among the $95 \%$ confidence interval. The result showed that the background were $763,66.92,52.84,238.82,39.65,60.18,28.73$ and $13.60\left(\mathrm{mg} \mathrm{kg}^{-1}\right)$ for the elements $\mathrm{Mn}, \mathrm{V}, \mathrm{Cr}, \mathrm{Co}, \mathrm{Cu}, \mathrm{Zn}, \mathrm{Pb}$ and $\mathrm{As}$, respectively.
\end{abstract}

Key Words: Urban river, Heavy metals, Background concentrations, Sediment, Regional geochemical baseline.

ᄂ - - - - - - - - - - - - - - - - - - - - - - - - - -

\section{INTRODUCTION}

Background concentrations of elements in soil, sediment may reflect basic information and inter-relationships within a given period and spatial scale ${ }^{1}$. For the impacts caused by anthropogenic contaminants from urban areas and industrial sites, the concentrations of element in sediment varied widely. Among the various contaminants, heavy metals are of particular concern for their environmental persistence and biogeochemical recycling and ecological risks. As a reference level for estimation the degree and extent of sediment contamination, the regional background values of elements, especially for heavy metals, are crucial for assessing environmental quality standards and establishing the impacts of anthropogenic contaminants.

Background concentrations of elements are highly dependent on the mineralogical composition of the parent material and on the weathering processes that have led to formation ${ }^{2}$. Therefore, although natural background concentrations in soil, sediment have been investigated in many countries and have laid the foundations for understanding natural element variation and in assessing soil contamination, it is still necessary to estimate local background concentrations. The further more, the sediments in urban river have been contaminated fiercely by anthropogenic such as industry, agriculture and human activity in the last decade, which along with the development of society and city.

The previous studies showed that the methods such as containing ratio calculation, regression analysis, correlation coefficients and principal component analysis were good for revealing the geochemical natural background concentrations of elements without any anthropogenic enrichment ${ }^{3-5}$. The reference element, a fundamental or conservative tracer of the natural metal bound phases, is assumed to have a uniform flux form the coastal bedrock. Various elements have been proposed in the literature to be the potential conservative reference element, such as $\mathrm{Al}, \mathrm{Fe}, \mathrm{Li}, \mathrm{Sc}$ and stable Cs. Among these elements, $\mathrm{Al}$ and $\mathrm{Fe}$ have been the most frequently used in the estuarine and coastal studies ${ }^{6,7}$, while $\mathrm{Li}, \mathrm{Sc}$ and $\mathrm{Cs}$ were used to a lesser extent ${ }^{8}$.

Tuohe river is the most important water course in the Suzhou city, northern Anhui province, China, which must be satisfied the requirement of sight, farmland irrigation and laundry and drinking, as an urban river. River of this system drain a large industrial, urban and agricultural area. The objectives of the present study were to measure the content of heavy metals, estimate the background concentration levels and calculate the regional geochemical baseline of the sediment from Tuohe River, Anhui province, China. 


\section{EXPERIMENTAL}

Description of study area: Tuohe river is one of the major tributaries of the Huaihe river, which originated in Shangqiu city, Henan province, flows Yongcheng, Suixi, Suzhou and Bengbu city. The whole length of the river is about 275.13 $\mathrm{Km}$ and its watershed is about $8500 \mathrm{Km}^{2}$. Suzhou city is located in the north part of Anhui Province, China, which is a developing city with the agricultural and coal industry as leading industry city (Fig. 1).

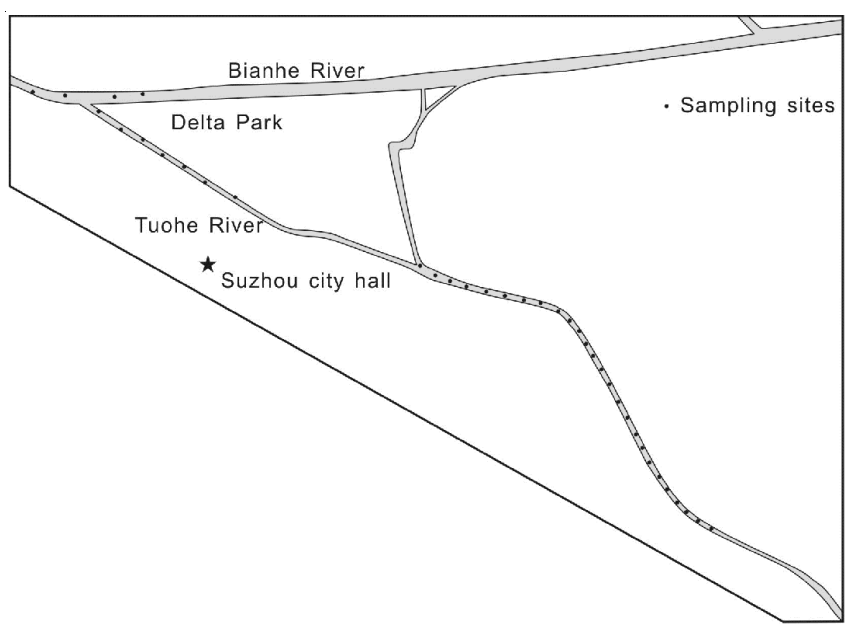

Fig. 1. Location of the study area and soil sampling sites

Sampling and analysis: Only the surface sediments (0-5 $\mathrm{cm})$ had been collected by using a homemade sediment sampler. A total of 37 sediment samples had been collected in the study area (Fig. 1). Samples were collected from 3-4 locations at a given site and mixed to improve site representation. Samples were firstly air-dried in natural condition and the debris of animals and plants had been removed by hands. Then the samples were powdered to 200 meshes after parching for $24 \mathrm{~h}$ with $80{ }^{\circ} \mathrm{C}$ in dryer.

Samples were condensed to be tablets by using a $30 \mathrm{t}$ condenser and then analyzed by X-ray fluorescence (Explorer 9000SDD) in the Engineering Research Center of Coal Exploration, Anhui Province. National standard sediment sample (GBW07307) is analyzed simultaneously for calibration and the relative standard derivation is less than $10 \%$, statistical analysis is performed by SPSS (version 11).

\section{RESULTS AND DISCUSSION}

Basic statistical parameters of the elemental contents: The statistical characteristics of concentration for heavy metals and correlated elements are present in Table-1. The compositions of the Upper Continental Crust ${ }^{9}$ are also presented. The average content of elements were arranged as follows: $\mathrm{Si}>\mathrm{Ca}>\mathrm{Al}>\mathrm{Fe}>\mathrm{K}>\mathrm{Mn}>\mathrm{Sr}>\mathrm{Co}>\mathrm{Zr}>\mathrm{Zn}>\mathrm{V}>\mathrm{Cr}>\mathrm{Cu}$ $>\mathrm{Pb}>\mathrm{Th}>$ As. Sediment samples in Tuohe river exhibit total depletion of elements $\mathrm{Al}, \mathrm{K}, \mathrm{Fe}, \mathrm{V}$ and $\mathrm{Cr}$ relative to the $\mathrm{UCC}$, otherwise the elements $\mathrm{Si}, \mathrm{Ca}, \mathrm{Co}, \mathrm{Cu}, \mathrm{Zn}, \mathrm{Sr}, \mathrm{Pb}, \mathrm{As}$ and $\mathrm{Th}$ are enrichment. In addition, the average values of 16 elements are as follows: (1) major elements (Al 3.07, Si 75.37, Ca 11.05, K 2.02, Fe 3.04); (2) heavy metals ( Mn $854 \mathrm{mg} \mathrm{kg}^{-1}$, V 69.61 $\mathrm{mg} \mathrm{kg}^{-1}$, Cr $53.42 \mathrm{mg} \mathrm{kg}^{-1}$ Co $245.64 \mathrm{mg} \mathrm{kg}^{-1}, \mathrm{Cu} 44.80 \mathrm{mg}$ $\mathrm{kg}^{-1}$, Zn $107.73 \mathrm{mg} \mathrm{kg}^{-1}$ Pb $33.45 \mathrm{mg} \mathrm{kg}^{-1}$, As $14.0 \mathrm{mg} \mathrm{kg}^{-1}$ ); (3) other trace elements ( $\mathrm{Sr} 431.62 \mathrm{mg} \mathrm{kg}^{-1}, \mathrm{Zr} 190.22 \mathrm{mg} \mathrm{kg}^{-1}$, Th $19.93 \mathrm{mg} \mathrm{kg}^{-1}$ ).

Conventional statistic approaches are normally used to analyze and assess interrelationship among elements in the sediments. Correlation analysis has been carried out in this study to check for geochemical associations and to ascertain the geochemical origin and behaviour in the sediments of urban river. The close inspection of correlation matrix is useful as it can point out associations between variables that can show the overall coherence of the data set and thus indicate the participation of the individual chemical parameters in several influence factors ${ }^{10}$. The correlation matrix of the elements in sediments is shown in Table-2. The critical value of correlation coefficient can be calculated as 0.35 , for there are 37 samples in total. It can be seen from Table- 2 that strong positive correlations were observed for $\mathrm{Fe}-\mathrm{Al}, \mathrm{Cu}-\mathrm{Zn}, \mathrm{Al}-\mathrm{V}$, Fe-Co, $\mathrm{Fe}-\mathrm{Mn}$ and $\mathrm{Al}-\mathrm{Cr}$, indicating the existence of a common source/ origin of these metals in samples.

Regional geochemical baseline of heavy metals: The regional geochemical baseline of heavy metals were reported by previous workers ${ }^{7,11}$. It is extremely important to identify anthropogenic and natural source and quantify its anthropogenic enrichment in the sediments. The proper reference element should be characterized by these factors, such as: (1) the reference element is acutely correlated to the element of interest; (2) the reference element is not added by anthropogenic sources; (3) the reference element is stable and is not subject to environmental influences; (4) the concentration of the reference element can be quantitatively determined accurately ${ }^{11}$. Thus, the elements $\mathrm{Fe}$ and $\mathrm{Al}$ were selected as the reference elements to develop the regional geochemical baseline of heavy metals. In addition, the advantages of using $\mathrm{Fe}$ and $\mathrm{Al}$ as the reference element are that they are major elements in the earth's crust and sediment and usually are only slightly influenced by anthropogenic inputs.

\begin{tabular}{|c|c|c|c|c|c|c|c|c|c|c|c|c|c|c|c|c|}
\hline & & & ATIS & $\begin{array}{l}\mathrm{AL} \mathrm{C} \\
\mathrm{OM} \mathrm{U}\end{array}$ & $\begin{array}{l}\mathrm{ARAC} \\
\mathrm{BAN}\end{array}$ & $\begin{array}{l}\text { ERIS } \\
\text { IVER } \\
\end{array}$ & $\begin{array}{l}\text { CS OF E } \\
\text { NORT }\end{array}$ & $\begin{array}{l}\text { TABLE } \\
\text { LEME } \\
\text { HERN }\end{array}$ & $\begin{array}{l}1 \\
\text { ITS CON } \\
\text { NHUI P }\end{array}$ & $\begin{array}{l}\text { CENTF } \\
\text { ROVIN }\end{array}$ & $\begin{array}{l}\text { ATION } \\
\mathrm{E}, \mathrm{CHI}\end{array}$ & $\begin{array}{l}\text { FOR SED } \\
\text { JA }(n=37)\end{array}$ & IMENT & & & \\
\hline \multirow{2}{*}{ Element } & $\mathrm{Al}$ & $\mathrm{Si}$ & $\mathrm{Ca}$ & $\mathrm{K}$ & $\mathrm{Fe}$ & $\mathrm{Mn}$ & $\mathrm{V}$ & $\mathrm{Cr}$ & $\mathrm{Co}$ & $\mathrm{Cu}$ & $\mathrm{Zn}$ & $\mathrm{Sr}$ & $\mathrm{Zr}$ & $\mathrm{Pb}$ & As & Th \\
\hline & & & $\%$ & & & \multicolumn{11}{|c|}{$\mathrm{mgkg}^{-1}$} \\
\hline Max & 3.65 & 87.41 & 20.46 & 2.35 & 4.05 & 1280 & 93.00 & 86.00 & 421.00 & 73.00 & 315.00 & 1102.00 & 287.00 & 73.00 & 23.00 & 31.00 \\
\hline Min & 2.15 & 63.00 & 4.82 & 1.83 & 1.76 & 450 & 49.00 & 24.00 & 106.00 & 23.00 & 29.00 & 232.00 & 112.00 & 19.00 & 7.00 & 12.00 \\
\hline St. Dev. & 0.32 & 5.87 & 3.43 & 0.13 & 0.51 & 207 & 11.20 & 13.66 & 68.99 & 14.59 & 81.55 & 221.97 & 35.75 & 14.49 & 4.33 & 5.12 \\
\hline Average & 3.07 & 75.37 & 11.05 & 2.02 & 3.04 & 854 & 69.61 & 53.42 & 245.64 & 44.80 & 107.43 & 431.62 & 190.22 & 33.45 & 14.00 & 19.93 \\
\hline Median & 3.12 & 75.31 & 10.56 & 2.03 & 3.15 & 820 & 66.00 & 54.00 & 252.00 & 41.00 & 67.00 & 336.00 & 184.00 & 26.00 & 14.00 & 19.00 \\
\hline UCC & 15.40 & 66.60 & 3.59 & 2.80 & 5.04 & 100 & 97.00 & 92.00 & 17.30 & 28.00 & 67.00 & 320.00 & 193.00 & 17.00 & 4.80 & 10.50 \\
\hline
\end{tabular}




\begin{tabular}{|c|c|c|c|c|c|c|c|c|c|c|c|c|c|c|c|c|}
\hline \multicolumn{17}{|c|}{$\begin{array}{c}\text { TABLE-2 } \\
\text { CORRELATION MATRIX OF ELEMENTS CONCENTRATIONS FOR SEDIMENTS } \\
\text { FROM URBAN RIVER IN NORTHERN ANHUI PROVINCE, CHINA }(\mathrm{n}=37)\end{array}$} \\
\hline & $\mathrm{Al}$ & $\mathrm{Si}$ & $\mathrm{Ca}$ & $\mathrm{K}$ & $\mathrm{Mn}$ & $\mathrm{Fe}$ & $\mathrm{V}$ & $\mathrm{Cr}$ & $\mathrm{Co}$ & $\mathrm{Cu}$ & $\mathrm{Zn}$ & $\mathrm{Sr}$ & $\mathrm{Zr}$ & $\mathrm{Pb}$ & As & $\mathrm{Th}$ \\
\hline $\mathrm{Al}$ & 1.00 & - & - & - & - & - & - & - & - & - & - & - & - & - & - & - \\
\hline $\mathrm{Si}$ & -0.52 & 1.00 & - & - & - & - & - & - & - & - & - & - & - & - & - & - \\
\hline $\mathrm{Ca}$ & 0.28 & -0.89 & 1.00 & - & - & - & - & - & - & - & - & - & - & - & - & - \\
\hline $\mathrm{K}$ & 0.40 & -0.21 & 0.26 & 1.00 & - & - & - & - & - & - & - & - & - & - & - & - \\
\hline $\mathrm{Mn}$ & 0.44 & -0.49 & 0.57 & 0.37 & 1.00 & - & - & - & - & - & - & - & - & - & - & - \\
\hline $\mathrm{Fe}$ & 0.92 & -0.60 & 0.43 & 0.47 & 0.62 & 1.00 & - & - & - & - & - & - & - & - & - & - \\
\hline $\mathrm{V}$ & 0.74 & -0.23 & -0.12 & 0.05 & 0.18 & 0.61 & 1.00 & - & - & - & - & - & - & - & - & - \\
\hline $\mathrm{Cr}$ & 0.63 & -0.34 & 0.16 & 0.07 & 0.16 & 0.61 & 0.48 & 1.00 & - & - & - & - & - & - & - & - \\
\hline Co & 0.72 & -0.43 & 0.24 & 0.20 & 0.32 & 0.78 & 0.47 & 0.60 & 1.00 & - & - & - & - & - & - & - \\
\hline $\mathrm{Cu}$ & 0.64 & -0.53 & 0.15 & -0.07 & 0.04 & 0.54 & 0.69 & 0.55 & 0.51 & 1.00 & - & - & - & - & - & - \\
\hline $\mathrm{Zn}$ & 0.52 & -0.31 & -0.06 & -0.32 & -0.13 & 0.36 & 0.76 & 0.48 & 0.35 & 0.87 & 1.00 & - & - & - & - & - \\
\hline $\mathrm{Sr}$ & 0.02 & -0.78 & 0.90 & 0.20 & 0.51 & 0.20 & -0.25 & -0.06 & 0.06 & 0.01 & -0.19 & 1.00 & - & - & - & - \\
\hline $\mathrm{Zr}$ & 0.35 & 0.05 & -0.15 & -0.35 & -0.01 & 0.30 & 0.31 & 0.30 & 0.52 & 0.22 & 0.21 & -0.29 & 1.00 & - & - & - \\
\hline $\mathrm{Pb}$ & 0.35 & -0.72 & 0.50 & -0.03 & 0.16 & 0.36 & 0.30 & 0.46 & 0.37 & 0.69 & 0.58 & 0.51 & -0.11 & 1.00 & - & - \\
\hline As & 0.17 & -0.40 & 0.36 & 0.16 & 0.44 & 0.26 & 0.21 & 0.03 & 0.09 & 0.14 & 0.12 & 0.39 & -0.20 & 0.25 & 1.00 & - \\
\hline Th & 0.37 & -0.49 & 0.43 & 0.36 & 0.39 & 0.44 & 0.20 & 0.14 & 0.13 & 0.21 & 0.04 & 0.46 & -0.21 & 0.29 & 0.36 & 1.00 \\
\hline
\end{tabular}

The element Al was selected as the reference element to develop the regional geochemical baseline of elements $\mathrm{Cr}, \mathrm{Zn}$, $\mathrm{V}$ and $\mathrm{Cu}$, for the correlation coefficients between $\mathrm{Al}$ and these elements were high than Fe (Table-2), whereas the Fe was selected to develop the regional geochemical baseline of elements $\mathrm{Pb}, \mathrm{As}, \mathrm{Mn}$ and Co oppositely. The developed regional geochemical baseline equations of the heavy metals elements are: $\mathrm{Cr}\left(\mathrm{mg} \mathrm{kg}^{-1}\right)=28.16+26.57 * \mathrm{Al}(\%), \mathrm{Zn}(\mathrm{mg}$ $\left.\mathrm{kg}^{-1}\right)=294.0+130.8^{*} \mathrm{Al}(\%), \mathrm{V}\left(\mathrm{mg} \mathrm{kg}^{-1}\right)=9.67+25.82 \mathrm{Al} *$ (\%), $\mathrm{Cu}\left(\mathrm{mg} \mathrm{kg}^{-1}\right)=43.44+28.7 * \mathrm{Al}(\%), \mathrm{Pb}\left(\mathrm{mg} \mathrm{kg}^{-1}\right)=2.19$ $+10.82 * \mathrm{Fe}(\%), \mathrm{As}\left(\mathrm{mg} \mathrm{kg}^{-1}\right)=7.28+2.21 * \mathrm{Fe}(\%), \mathrm{Mn}\left(\mathrm{mg} \mathrm{kg}^{-1}\right)$ $=99.0+248.3 * \mathrm{Fe}(\%), \mathrm{Co}\left(\mathrm{mg} \mathrm{kg}^{-1}\right)=74.35+105.3 * \mathrm{Fe}(\%)$.

Background concentrations of heavy metals: The present study revealed that background concentrations were determined by analyzing samples, which were unaffected, or at least minimally affected, by human activities ${ }^{4}$ or calculated by regression analysis which based on the normalized element to select the upper $95 \%$ confidence interval of the linear regression between reference element and element of interest $t^{12,13}$. The median of elements in present samples is close to the average values for all 16 elements, indicating a similar statistical distribution pattern for different elements in sediments samples. Thirty seven sediment samples could be derived from a single and uniform parent material for the relatively small variability and the narrow range between minimum and maximum values for all elements. In addition, this view also supported by the scene that almost all the sediment samples are within the $95 \%$ prediction interval in Fig. 2.

Otherwise, the concentrations of heavy metals are also influenced by the other factors, rather than only inherited from the parent materials, for the concentrations values varied slightly. Since the sediment samples are affected by the discharges form anthropogenic sources, the background concentrations of sediment could only be calculated by regression analysis. The relationships between heavy metals and reference elements in the baseline data set can show the range of naturally occurring concentrations of trace metals. The element $\mathrm{Al}$ and $\mathrm{Fe}$ are be selected as reference element, in concretely, $\mathrm{Al}$ was selected as the concentration normalizer for $\mathrm{Cr}, \mathrm{Zn}, \mathrm{V}$ and $\mathrm{Cu}$, while $\mathrm{Fe}$ was used as the normalizing element for elements $\mathrm{Pb}$, As,
$\mathrm{Mn}$ and Co. The linear regression results, as well as the upper $95 \%$ confidence intervals and prediction intervals, are illustrated in Fig. 2. All data-points which fall inside the $95 \%$ confidence band can be designated as natural sediments without any contamination, while points above this area can be considered as sediments with heavy metals accumulated from anthropogenic source. In the regression plot between the total metal concentrations and the appropriate normalizers, the data points below the upper $95 \%$ confidence interval limit probably originated from natural sources. Thus, the regional background concentrations of heavy metal elements could be calculated by the average values of the natural sediment samples. The results showed that the quantity of natural sediment samples which upper the $95 \%$ confidence interval in number be 15,11,12,13,16,13, 12 and 14 for elements As, $\mathrm{Zn}, \mathrm{V}, \mathrm{Cu}, \mathrm{Cr}, \mathrm{Pb}, \mathrm{Mn}$ and $\mathrm{Co}$, respectively (Fig. 2). Thus, the background concentrations of the elements $\mathrm{Cr}, \mathrm{Zn}, \mathrm{Pb}, \mathrm{V}$, $\mathrm{Cu}, \mathrm{As}, \mathrm{Mn}, \mathrm{Co}$ be calculated by the average value of these natural sediment samples. And the results were 763, 66.92, $52.84,238.82,39.65,60.18,28.73$ and $13.60\left(\mathrm{mg} \mathrm{kg}^{-1}\right)$ for the elements $\mathrm{Mn}, \mathrm{V}, \mathrm{Cr}, \mathrm{Co}, \mathrm{Cu}, \mathrm{Zn}, \mathrm{Pb}$ and $\mathrm{As}$, respectively.

\section{Conclusion}

The concentrations of chemical elements in the sediment samples from urban river were measured and a series of conclusions could be obtained: The average values of $\mathrm{Mn}$ concentration was $854 \mathrm{mg} \mathrm{kg}^{-1}$, followed by $\mathrm{V}, \mathrm{Cr}, \mathrm{Co}, \mathrm{Cu}$, $\mathrm{Zn}, \mathrm{Pb}$ and $\mathrm{As}$ at 69.61, 53.42, 245.64, 44.80, 107.73, 33.45 and $14.0 \mathrm{mg} \mathrm{kg}^{-1}$, respectively. The decreasing trend of average metal levels was as follows: $\mathrm{Mn}>\mathrm{Co}>\mathrm{Zn}>\mathrm{V}>\mathrm{Cr}>\mathrm{Cu}>\mathrm{Pb}$ $>$ As.

Multivariate statistical analysis (correlated analysis and regression analysis) have been processed for obtained the regional geochemical baseline and the background concentrations of heavy metals, the results implied that the $\mathrm{Al}$ and $\mathrm{Fe}$ was selected as the reference elements for $\mathrm{Cr}, \mathrm{Zn}, \mathrm{V}, \mathrm{Cu}$ and $\mathrm{Co}, \mathrm{Mn}, \mathrm{As}, \mathrm{Pb}$, respectively. The background concentrations were 763, 66.92, 52.84, 238.82, 39.65, 60.18, 28.73 and 13.60 $\left(\mathrm{mg} \mathrm{kg}^{-1}\right)$ for the elements $\mathrm{Mn}, \mathrm{V}, \mathrm{Cr}, \mathrm{Co}, \mathrm{Cu}, \mathrm{Zn}, \mathrm{Pb}$ and $\mathrm{As}$, respectively. 

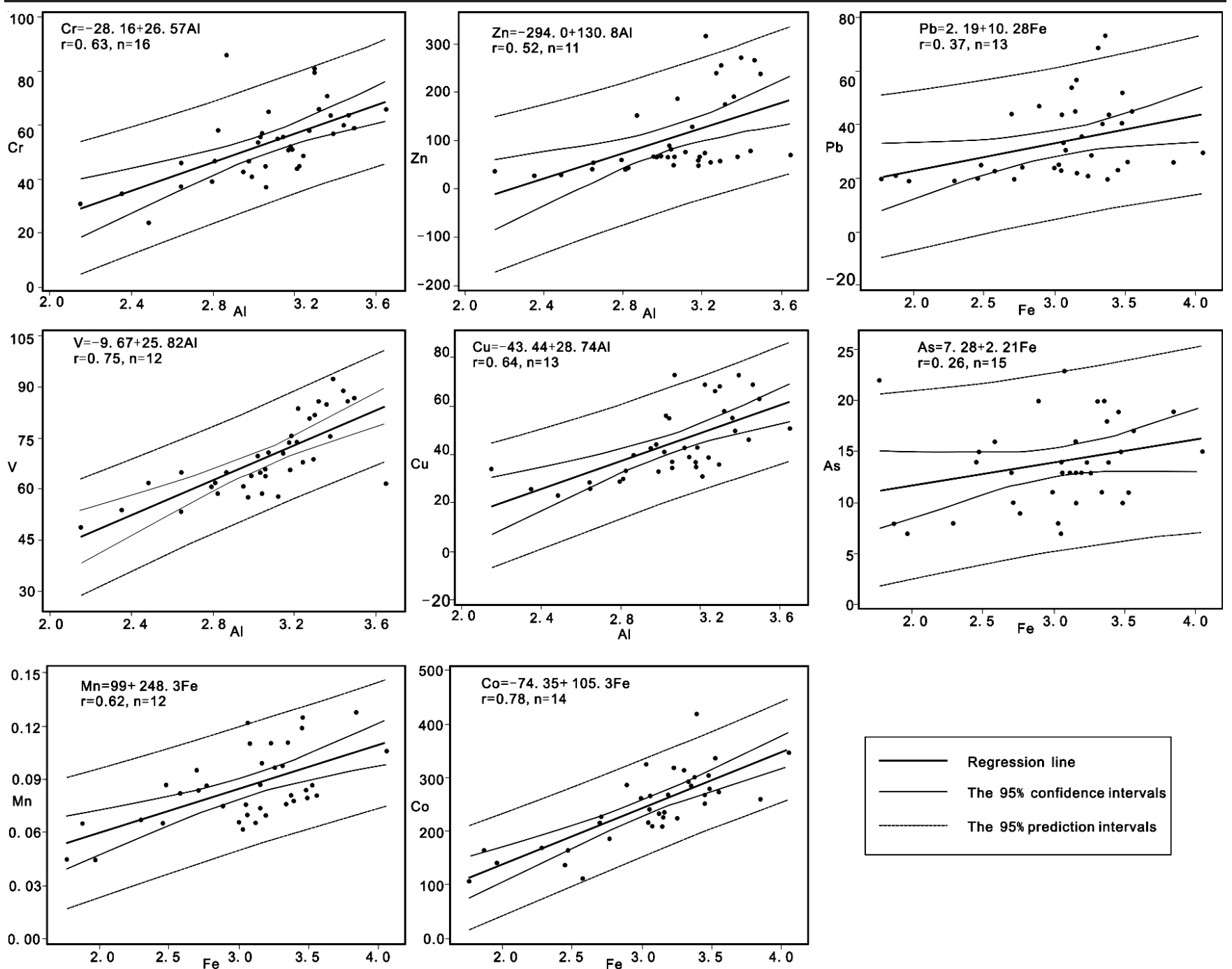

Fig. 2. Scatter plots of the linear regression models between the heavy metals elements and reference elements ( $\mathrm{Al}$ and $\mathrm{Fe})$ from urban river in northern Anhui province, China $(\mathrm{N}=37)$; The $\mathrm{r}$ and $\mathrm{n}$ denote the correlation matrix and the number of upper $95 \%$ confidence intervals, respectively

\section{ACKNOWLEDGEMENTS}

The study was supported by the National Nature Science Foundation of China (41173106) and Anhui province Department of education Natural Science Foundation (KJ2013B289). All the samples were tested in the Engineering Research Center of Coal Exploration, Anhui Province.

\section{REFERENCES}

1. H.M. Chen, Environmental Soil Science, Science Publishing House, Beijing, p. 238 (2005) (in Chinese)

2. F.M.G. Tack, M.G. Verloo, L. Vanmechelen and E. Van Ranst, Sci. Total Environ., 201, 113 (1997).

3. W.X. Liu, X.D. Li, Z.G. Shen, D.C. Wang, O.W.H. Wai and Y.S. Li, Environ. Pollut., 121, 377 (2003).
4. Y.Z. Su and R. Yang, J. Geochem. Explor, 98, 57 (2008).

5. C.Y. Lin, M.C. He, Y.X. Li and S.Q. Liu, Chemi der Erde, 72, 23 (2012).

6. K.C. Schiff and S.B. Weisberg, Environ. Res., 48, 161 (1999).

7. M. Mil-Home, R.L. Stevens, I. Cato and F. Abrantes, Environ. Pollut., 148, 418 (2007).

8. D.H. Loring, J. Marine Sci., 48, 101 (1991).

9. R.L. Rudnick and S. Gao, Treatise Geochem., 3, 1 (2003).

10. A. Cobelo-Garcia and R. Prego, Estuarine, Coastal Shelf Sci., 60, 695 (2004).

11. S. Luoma, In eds.: R. Furness and P. Rainbow, Processes Affecting Metal Concentrations in Estuarine and Coastal Marine Sediments, Heavy Metals in the Marine Environment, CRC, Boca Raton, FL,USA, pp. 51-66 (1990).

12. S.J. Schropp, F.G. Lewis and H.L. Windom, Estuarine, 13, 227 (1990).

13. J.P. Coakley and D.J. Poulton, Estuarine, 16, 873 (1993). 